\title{
Through the Eyes of the Delusional Ones
}

Rasha Awale

https://doi.org/10.30608/HJEAS/2021/27/1/16

Hanson, Victor Davis. The Case for Trump. New York: Hachette Book Group Inc., 2019. 355 pages. ISBN 978-5416-7353-3. Ebook. $\$ 16.81$.

Less than a year after the surprising electoral victory of Donald Trump, Harvard law school Professor Jack Goldsmith wondered in The Atlantic: "Will Donald Trump Destroy the Presidency?" The article mainly approached Trump's norm-shattering attitude, his unhinged behavior, and the way in which checks and balances could help in preventing him from breaking the law. Goldsmith, at the time when Trump's presidency had entered its final days, acknowledged that despite impeachment, and his proven incompetence in handling the Covid19 outbreak, he had remained the presumptive Republican nominee for 2020. Although claiming that he had destroyed the institution of presidency might be an overstatement, it could hardly be denied that Trump's norm-breaking cruelties and vicious attitudes would be seen, be that an eventuality, as having served his winning the election and building a strong base of supporters, thus, as having changed the standards of who is competent enough to run for presidency.

No one could have accurately predicted the results of the 2020 elections, but what we can do is to understand the 2016 elections, and how the controversial TV star Donald Trump managed to win the votes of 62,984,827 Americans. Victor Davis Hanson's 2019 book, The Case for Trump, is an attempt to comprehend the 2016 results, and how Trump won a straight party ticket energizing the Republican base, and how he won the swing states of the Midwest. One of Trump's advocates himself, Hanson, Stanford University professor, and senior fellow 
at Hoover Institution, describes the reasons that have led him to change his own political affiliation from the Democratic Party to the Republican Party, and to vote for Trump out of frustration and resentment to what he considered to be the Democratic Party's takeover by radical progressives who alienated the White working class (Chapter one).

The book is divided into five parts, all including three chapters, except for the last one. In the first part, Hanson attempts to answer the question: "What and who created Trump?" This chapter, "The Two Americas," explains the mechanism by which Trump won $90 \%$ of the Republican votes, and how his campaign promises embraced and galvanized the disenchanted White working-class voters, who were angry over their perceived economic and cultural decline in states like Michigan, Ohio, Pennsylvania, and Wisconsin. "Trumpism" outlines Trump's stance on foreign policy, including avoiding adventures abroad by refusing to interfere on behalf of "ungrateful" others; maintaining U.S. military superiority; questioning the U.S.'s long-term commitments abroad (from NATO through the UN to the Middle East peace process); standing up to Iran, North Korea, and China; and defeating ISIS. However, a close reading of these stances cannot but question the author's attempt to give a nonexistent depth to Trump's sloppy foreign policy. "Modern Day Presidential" examines the pre-election Trump TV persona, where Trump's charisma, humor, and presence portrayed him as a successful businessman, who rewarded those working hard, and fired the incompetent. In retrospect, during his presidential campaign and after becoming president, Trump maintained his manners, and treated voters as viewers of a show, addressing them in plain, entertaining language, using swear words and nicknames.

The second part, "An Establishment without Answers," starts with "Democratic Tribalism," addressing the way Trump's rivals—-both Republicans and Democrats—presented their opposition to Trump as the basis of their campaigns, without providing a serious alternative agenda that might have been more appealing to the voters. "Republicans Lose 
While Winning" analyzes the Republican Party's unsuccessful presidential campaigns (George H. W. Bush in 1992, Bob Dole in 1996, John McCain in 2008, and Mitt Romney in 2012), claiming that those candidates had lacked the charisma, stamina, and crudity needed to energize the voters and defeat the more energetic democratic candidates. "The Ancient Regime" highlights the efforts coordinated by major media channels, journalists, establishment politicians, and the "deep state" agents to undermine Trump's presidency by overriding his orders and purposely keeping information from him. The third part, "Trump Metaphysics," includes “Trump on Decline," which justifies Trump's "Make America Great Again" slogan by clarifying what Trump considers to be the reasons behind America's decline — high crime rates, failed infrastructure, homelessness, unemployment—and Trump's remedy to this perceived decline by putting American interests ahead, demanding fair trade, restricting immigration, and reducing US commitments abroad. "Never Hillary" claims that the Trump presidency was the result of many voters resenting the nomination of Hillary Clinton; this section is then followed by numerous pages devoted to covering the Clintons' controversies since the 1990s. In a surprising move, Hanson adds Russia's interference in the 2016 election to his list of controversies without regard to the actual findings of the FBI investigation, which uncovered links between Trump's associates and Russian officials, who worked together to release false and damaging information against the Clinton campaign. In "New/Old Crude Messenger," Hanson compares the scandals surrounding Trump's character with those of previous presidents', to suggest later that the liberal media exaggerated his flaws to drive down his popularity. This narrative ignores the fact that it is natural for a president to become the target of the media. Nevertheless, it was not the media who came up with such attacks, it was Trump himself who acted, talked, and tweeted in a way that evoked such coverage. The Fourth part includes "End Trump," which claims a collective effort was made by the Democrats to hinder the Trump presidency to undermine the Republican establishment, 
and the "deep state." Previously, Hanson described Trump as "the chemotherapy" needed to "kill the cancer," that is, the bureaucracy of the proverbial deep state (Chapter three), the ballistic missile "against those who had been showering the working class with crude and often racist attacks" (Chapter three), and even likened him to Alexander the Great (Chapter nine). In "Trump, the Tragic Hero," Hanson argues that Trump fits the description of a "tragic hero," who fights alone, and whose service is never rewarded or valued by those whom he serves. "Mr. Trump Goes to Washington" disregards the fact that Trump inherited a healthy economy from president Obama, and hails the 2017-2018 economic growth as Trump's main achievement. The last part of the book, "Trump Trudges on: The 2018 Midterms and Beyond," tackles the American society's division after the 2016 elections, and the Democrats' blue wave of 2018. This chapter finishes by Hanson dismissing the possibility of Trump's impeachment, and positing Trump's chances to win a second term — both have proved wishful thinking since then.

By way of a conclusion, Hanson's book provides a new insight into Trump's presidency, using the logic of those who elected him without questioning them as sexist, racist, xenophobic, Islamophobic, and so on. His book is an attempt to differentiate the message (Trump's campaign promises) from the messenger (Trump's character and personality), and to highlight the alternative factors that played a role in determining the results of the 2016 election.

Trump has always been a controversial figure who will attract attention and provoke media coverage whether by making an outrageous comment, tolerating thuggery in his rallies, spreading false information or attacking his opponents. However, in the midst of a pandemic and a stumbling economy, controversy is not what comes to mind when people are choosing their future leader, for being the commander-in-chief of one of the most powerful nations on earth is not a reality show, and witnessing Trump's constant drama and turpitudes is not a 
guilty pleasure, rather it is like being in dire straits without a way out. In April 2020, Trump tweeted, "REOPEN OUR COUNTRY," cheering protesters against social distancing restrictions and calling for an end to the coronavirus lockdown. Before that, he had downplayed the virus, compared it to a regular flu, and claimed that it would disappear miraculously. By the time of writing this review the death toll of Covid-19 in the United States has surpassed 540,000 Americans; if anything, the crisis has shown that there is no way to excuse Trump's astounding ineptitude, and the absence of his competence and leadership. Trump is "dangerously unpredictable" as Noam Chomsky described him, he refuses to accept criticism or to evaluate his misconduct as Robert Kagan asserted, and his main concerns are his own interests and political gains, as his former advisor, John Bolton affirmed (Chapter 14).

Furthermore, the most alarming aspect of the Trump phenomenon is that when Trump took office, many believed that even though he did not have the required qualifications and experience, he will be surrounded by professionals and experts who are going to advise and guide him. Yet many of Trump's influential aids resigned or were fired-mostly for disagreeing with him - and the ones who remained certainly avoided any clash with him that might lead them to similar fate (Packer). There is no doubt that many Trump supporters will stand behind him no matter what. But among the over 60 million Americans who voted for Trump in 2016, and the over 70 million who voted for him in 2020, there are also the ones who felt betrayed and neglected by the political elite in Washington. Those who believed that trillions of US taxpayers' money were spent on building, aiding, and protecting other countries while Americans were struggling to find jobs, their healthcare, education infrastructures, and industries were barely managing if not falling apart. They voted for Trump not because he was the best candidate but because many of them trusted him the more they mistrusted the political elite. Trump presented himself as one of them, a businessman 
negotiating a deal: elect me and I will put America first, elect me and I will make America great again, and they were deluded.

In Hanson's logic, Trump is a tragic hero who came to fix things that should have been fixed long ago, and once his mission is done he will be discharged with no gratitude. What remains to be answered is not whether Trump has fixed anything but whether the damage he caused, enabled, and exposed can ever be fixed. The delusional are not only the one who believed and elected Trump, but also the ones who think Trump is America's sickness while he is merely a symptom.

University of Debrecen

\section{Works Cited}

@ realDonaldTrump (Donald Trump). "REOPEN OUR COUNTRY” Twitter, May 182020.

Web. 12 July 2020.

Bolton, John. The Room Where it Happened: A White House Memoir. E-book. Simon and Schuster, 2020.

Chomsky, Noam. "Noam Chomsky on the New Trump Era." Interview by Mehdi Hasan. YouTube, 25 Nov. 2016. Web. 28 Aug. 2020.

Did Trump Create or Inherit the Strong Economy? United States Congress, Joint Economic Committee: Congressman Don Beyer, Vice Chair 4 Feb. 2020. Web. 16 Apr. 2020.

Goldsmith, Jack. "Will Donald Trump Destroy the Presidency?" The Atlantic. Oct. 2017. Web. 4 Apr. 2020.

Kagan, Robert. "Donald Trump cannot take criticism. Imagine such a person as president." Chicago Tribune. 11 Aug. 2016. Web. 10 Sept. 2020. 
Packer, George. "The President Is Winning His War on American Institutions: How Trump is destroying the civil service and bending the government to his will." The Atlantic. Apr. 2020. Web. 16 Aug. 2020. 